\title{
The Influence of Female Executives on Corporate Behavior and Performance: A Review
}

\section{-Based on the Financial and Non-Financial Perspective}

\author{
Meng Tang, Jun Xu \\ School of Management, Jinan University, Guangzhou, China \\ Email: tangmeng0912@163.com, 783564261@qq.com
}

Received 2 September 2015; accepted 15 September 2015; published 18 September 2015

Copyright (C) 2015 by authors and Scientific Research Publishing Inc.

This work is licensed under the Creative Commons Attribution International License (CC BY). http://creativecommons.org/licenses/by/4.0/

(c) (i) Open Access

\begin{abstract}
In recent years, the quantity of female executives in the companies of is rising, some countries even raising a mandatory requirement about the proportion of female executives on the company. Women are increasingly attracting the attention of theory and practice fields, so does the discussion of the role of senior women. This article reviews the research about how female executives influence the corporate behavior and performance from the perspective of finance and non-finance, analyses the deficiency of related research and points out the direction for future research.
\end{abstract}

Keywords

Women Executives, Conduct and Performance of Company, Financial Perspective, Non-Financial Perspective

\section{Introduction}

With the development and prosperity of social economy, the role of women has drawn more and more attention. Meanwhile, the role is more and more important. As a result, the number of female executives in the company also increases. Burke [1] [2] report shows that male CEOs realize female executives could make an unique and positive contribution, the proportion of senior women in companies of some countries is put forward as the mandatory requirements. For example, Sweden required that female directors should not be less than $40 \%$ after 2008 [3], France also followed the steps of Sweden, asked in France's biggest listed companies or unlisted 
companies (more than 500 employees, and turnover in the company for more than 500 million euros), women directors should not be less than $40 \%$. Female executives have been a topic of discussion. Despite the increase in female executives' representation of support and opposition breaking out, most of the research shows that company executives' gender diversity exists positive role. So what effect will female executives bring to conduct and performance for the company? This paper reviews and presents the previous research, trying to answer the above questions from the perspective of financial and non-financial.

\section{The Influence on Corporate Behavior and Performance: Based on the Financial Perspective}

\subsection{Female Executives and M \& A}

Levi, etc. [4] argued that because of the less overconfidence and the more risk-averse, women will not overestimate the benefits of M \& A. They chose more than four hundred M \& A cases in 1997-2009 as the research object, analyzing the impact of executives gender on $M \& A$ activity and results, founding that the company increases a female executives, $M \&$ A activity will reduce $7.6 \%$ and $M$ \& A premium will reduce by $15.4 \%$. Similarly, Huang and Kisgen [5] using the double differences method in the empirical framework, controlling related variables, found the companies with women excutives had a lower likelihood of acquisitions. At the same time, the female executives acquisitions will generate higher announcement returns than male executives. Similarly, Huang Xu [6] focusing on 144 manufacturing enterprises of A-share listed companies in China from 2006 to 2008, studied the effect that characteristic of the background of the executives of listed companies bring on mergers and acquisitions behavior, founding that female executives could inhibit the executive team overconfidence and irrational behavior in $\mathrm{M} \& \mathrm{~A}$.

\subsection{Female Executives and Earning Quality}

Earlier studies explain the effect of female executives on the quality of the surplus based on the gender difference of business ethics. Krishnan and Parsons [7] collected the related data of fortune 500 companies in the United States, regarding sustainability, robustness, surplus earnings smoothness and loss aversion degree as indicators of the quality of the surplus, using the method of matching, founding that women excutives significantly improved the quality of the surplus.

Along with the research continuously going deep, argumentation became more rigorous. Srinidhi [8] argued women could improve corporate governance and the quality of the surplus in four aspects, such as more independence, more different points of view, less patient about opportunism behavior, more risk-averse and overconfidence. They found that the higher the female participation in the board of directors, the higher the earnings quality. Zhou [9] found that women could significantly improve the existence of corporate accounting conservatism. Simon [10] further shrank the scope of female executives, only researched the relationship between gender of CEOs and accounting conservatism. Simon, etc integrated women's conservative mentality and morality with accounting conservatism, founding that if a company's CEO is women, its accounting robustness is stronger, further, when companies face a greater risk of litigation and acquisition, conservative mentality of female CEOs are particularly obvious in the financial report, which is consistent with traditional cognition.

\subsection{Female Executives and Corporate Performance}

What researchers concern in this field is whether female executives affect corporate performance? If the influence exists, is it positive or negative? Unlike other research angle of views about female executives, this kind of research is mainly from the early upper echelon theory to the current resource dependence theory and human capital theory Angle of view, the conclusions also being quite inconsistent, divided into positive influence , negative influence and no significant influence.

\subsubsection{Positive Influence}

Using the data of 2001-2004 of Catalyst [11], Francoeur etc empirically test women directors and women senior managers personnel's impact on corporate performance. They based on agency theory and stakeholder theory, founding that in the complex business environment, high proportion of women senior managers will increase significantly the company excess earnings (monthly excess return of $0.17 \%$, excess return of $6 \%$ three years). 
Ren Ting and Wang Zheng [12] integrated resource dependence theory and the theory of human capital, discussing the relationship between Chinese female executives and corporate performance in private enterprises. Putting two relations between human capital and social capital under the background of two regulating variable for the first time, they concluded that female executives could improve enterprise performance outstandingly. with the increase of female executives' human capital and social capital, the effect on the promotion of enterprise performance increases. This further enriched the Chinese studies of female executives.

\subsubsection{Negative Influence}

Taking 1939 American listed companies of 1996-2003 as samples, Adams and Ferreira [13] test empirically the influence female executives had on corporate governance and the value of the company. After controlling for endogeneity, they found that women could significantly improve corporate governance, but had a significant negative impact on the value of the company.

\subsubsection{No Significant Influence}

There are also some empirical results showing that there is no significant correlation between female executives and corporate performance. Based on the resource dependence theory, human capital theory, agency theory and social psychological theory, studying the standard \& poor's 500 index of 640 companies in the United States, measuring business performance with Tobin's Q and return on assets, Carter [14] concluded that women directors have no significant influence on corporate performance. Chen Lin [15] studied the influence Chinese female executives had on corporate performance, using the research thought of Carter and adopting virtual variable and ratio method to measure female executives, she found no significant correlation between two.

\section{The Influence on Corporate Behavior and Performance: Based on the Non-Financial Perspective}

\subsection{Female Executives and Charitable Donations}

Studies of relation of the two variable unfold mainly from managers character and principal-agent theory of cross paths. Wang and Coffey [16] selected the 78 companies in the fortune 500 data, from the women's social and economic background and tendency to non-profit two perspective, using multiple regression analysis. it was showed that women directors gave a less significant positive influence on the company's charitable. In this study, however, the quantity of sample data is small, meaning the problem of insufficient representative. Otherwise, the author assumed that there is no direct relationship between charity and profitability, obviously, this hypothesis were yet to be proven.

On the basis of Wang and Coffey, Williams [17] made more rigorous empirical testing. Williams expanded the size of the sample, collected the data from 185 companies and joined join the company's performance and reputation to test model as control variable, making up previous research. The study found that the correlation between women directors proportion and adjusted charitable donation was significantly positive. In specific areas for donations, it was significantly positive with community service, and art, no significant correlation with field of education and public policy, which was not completely consistent with the results of interview and questionnaire survey of women-women tend to be more funding for education career, suggesting that women are not “unity”. Unfortunately, the motivations behind the more donation female make than male still suspended and unresolved.

In recent years, scholars have a different approach-from the Care ethics of feminism. Several scholars began to analyze the relationship between the two from the different situations. Xingqiang Du and Wentao Feng [18], Zhou [9] empirically researched the impact female executives made on charitable giving, founding that senior women significantly increased the charity level of listed companies. In addition, they found that women independent directors could promote the level of charitable giving, but the promoting effect significantly reduced in the state-owned listed companies.

\subsection{Female Executives and Company's Reputation}

Brammer [19] selected 199 UK companies, divided the company into eight industry and scored between 1 - 10 points according to the standard of nine reputation, founding that the existence of the female executives does in- 
crease the company's reputation, meanwhile, founding that the proportion of senior women in different departments made different impact on the company's reputation, meaning that female executives in business activities close to the end consumer sector could increase significantly company reputation, but the increase of production department of senior women would reduce the company's reputation.

\section{The Prospect of Research in the Future}

\subsection{Improving Measurement Method}

So far, the measurement about female executives mostly focuses on the measure of female CEOs or female directors, so, future research scope of female executives can be further expanded to women supervisors and women senior managers, so as to improving the robustness of the empirical results.

\subsection{Broadening the Research Field}

Research on the effects of female executives of the company belongs to one of the crossing field between finance and other subjects, therefore, multidisciplinary cross and fusion methods in the future can be adopt to research impacts women executives have on other firm behavior and performance, such as further analysing influences on executive pay, incentive mechanism and performance evaluation decisions.

\subsection{Exploring Transmission and Process Mechanism Female Executives Influencing Companies}

There is strong endogenous between Female executives and corporate behaviors and performance .We need to tap into the intermediary variables, adjust or common cause which may play an important role in the both relationships, and further reveal the impact mechanism female executives make on corporate behaviors and performance.

\subsection{Conducting Researches Conforms to the Situation of China}

Studies of female executives in foreign countries are in great abundance, but are rare in domestic. Compared with foreign enterprises, Chinese enterprises are provided with a certain cultural tradition and economic and political background. Under the influence of the economic transformation, the internal process of the impact of female executives on corporate behavior and performance is perhaps more complex. There are large differences between different parts of the systematic environment in China. As a result, future research needs to have more empirical research on different regions and industries.

\section{References}

[1] Burke, R.J. (1994) Benefits of Women on Corporate Boards of Directors as Reported by Male CEOs'. Psychological Reports, 75, 329-330. http://dx.doi.org/10.2466/pr0.1994.75.1.329

[2] Burke, R.J. (1994) Women on Corporate Boards of Directors. Views of Canadian Chief Executive Officers'. Women in Management Review, 9, 3-10.

[3] Francoeur, C., Labelle, R. and Desgagne, B.S. (2008) Gender Diversity in Corporate Governance and Top Management. Journal of Business Ethics, 81, 83-95. http://dx.doi.org/10.1007/s10551-007-9482-5

[4] Levi, A., Li, K. and Zhang, F. (2014) Director Gender and Mergers and Acquisitions. Journal of Corporate Finance, 28, 185-200. http://dx.doi.org/10.1016/j.jcorpfin.2013.11.005

[5] Huang, J. and Kisgen, D.J. (2013) Gender and Corporate Finance: Are Male Executives Overconfident Relative to Female Executives? Journal of Financial Economics, 108, 822-839. http://dx.doi.org/10.1016/j.jfineco.2012.12.005

[6] Huang, X., Xu, C.X. and Li, W.M. (2013) The Chinese Listed Company Executives Background Characteristics Study of the Impact on the Enterprise M\&A Behavior. Journal of the Macroeconomic Research, 10, 67-73.

[7] Krishnan, G.V. and Parsons, L.M. (2008) Getting to the Bottom Line: An Exploration of Gender and Earnings Quality. Journal of Business Ethics, 78, 65-76. http://dx.doi.org/10.1007/s10551-006-9314-z

[8] Srinidhi, B., Gul, F.A. and Tsui, J. (2011) Female Directors and Earnings Quality. Contemporary Accounting Research, 28. http://dx.doi.org/10.1111/j.1911-3846.2011.01071.x

[9] Zhou, Z.J. (2014) The Female Directors Has Affected the Enterprise Charity?_-Based on the Empirical Study of Listed 
Companies in China. Journal of Shanghai University of Finance and Economics, 16, 78-85.

[10] Ho, S.S.M., Li, A.Y.S., Tam, K. and Zhang, F. (2014) CEO Gender, Ethical Leadership, and Accounting Conservatism. Journal of Business Ethics, 157, 351-370.

[11] Francoeur, C., Labella, R. and Martinez, I. (2008) Governance and the Decision to Issue a Profit Warning. Canadian Journal of Administrative Sciences, 25, 317-333.

[12] Ren, T. and Wang, Z. (2010) Women in Senior Management Team's Influence on Enterprise Performance: Based on the Research on China's Private Enterprises. Journal of Nan Kai Business Review, 13, 81-91.

[13] Adams, R.B. and Ferreira, D. (2009) Women in the Boardroom and Their Impact on Governance and Performance. Journal of Financial Economics, 94, 291-309.

[14] Carter, D.A., et al. (2010) The Gender and Ethnic Diversity of US Boards and Board Committees and Firm Financial Performance. Corporate Governance. An International Review.

[15] Chen, L., Wei, L.W. and Qiao, Z.L. (2013) The Female Executives of Listed Companies in China's Impact on Corporate Performance Analysis. Journal of Northwestern Polytechnical University (Social Science Edition), 33, 45-50.

[16] Wang, J. and Coffey, B.S. (1992) Board Composition and Corporate Philanthropy. Journal of Business Ethics, 11, 771-778. http://dx.doi.org/10.1007/BF00872309

[17] Williams, R.J. (2003) Women on Corporate Boards of Directors and Their Influence on Corporate Philanthropy. Journal of Business Ethics, 42, 1-10. http://dx.doi.org/10.1023/A:1021626024014

[18] Du, X.Q. and Feng, W.T. (2012) Female Executives, Institutional Environment and Charity. Journal of Economic Management, 503, 53-63.

[19] Brammer, S., Millington, A. and Pavelin, S. (2009) Corporate Reputation and Women on the Board. British Journal of Management, 20. http://dx.doi.org/10.1111/j.1467-8551.2008.00600.x 